\title{
Considerations in the Methodology for the Technical-Environmental Viability of Sanitary Landfills in Rural Communities. Northern Case of the Province of Santa Elena, Ecuador
}

\author{
Fernando Morante-Carballo ${ }^{1,2,3^{*}}$, Boris Apolo-Masache ${ }^{1,4}$, Paúl Carrión-Mero ${ }^{1,4}$, Bolívar Cedeño ${ }^{5}$, Javier Montalvan- \\ Toala $^{6}$ \\ ${ }^{1}$ Centro de Investigaciones y Proyectos Aplicados a las Ciencias de la Tierra (CIPAT), ESPOL Polytechnic University,Campus \\ Gustavo Galindo Km 30.5 Vía Perimetral, Guayaquil 09-01-5863, Ecuador \\ ${ }^{2}$ Geo-recursos y Aplicaciones (GIGA), ESPOL Polytechnic University, Campus Gustavo Galindo Km 30.5 Vía \\ Perimetral,Guayaquil 09-01-5863, Ecuador \\ ${ }^{3}$ Facultad de Ciencias Naturales y Matemáticas (FCNM), ESPOL Polytechnic University, Campus Gustavo Galindo Km. 30.5 \\ Vía Perimetral, Guayaquil 09-01-5863, Ecuador \\ ${ }^{4}$ Facultad de Ingeniería en Ciencias de la Tierra (FICT), ESPOL Polytechnic University, Campus Gustavo Galindo Km 30.5 \\ Vía Perimetral, Guayaquil 09-01-5863, Ecuador \\ ${ }^{5}$ Independent consultor, Milagro-Guayaquil 091050, Ecuador \\ ${ }^{6}$ Facultad de Ciencias de la Ingeniería, Centro de Investigación e Innovación de Geociencias (CIGEO), Universidad Estatal \\ Península de Santa Elena (UPSE), Avda. principal La Libertad-Santa Elena, La Libertad 240204, Ecuador
}

Corresponding Author Email: fmorante@espol.edu.ec

https://doi.org/10.18280/ijsdp.160211

Received: 2 January 2021

Accepted: 6 April 2021

\section{Keywords:}

Key Factor Matrix, sanitary landfill, solid waste, leached, Manglaralto commune, Ayangue commune

\begin{abstract}
This research focuses on providing a solution to rural sectors' problems regarding solid waste management and final disposal. It considered the Sanitary Landfill (SL) technicalenvironmental viability for rural communities in the north of Santa Elena-Ecuador. The objective is to propose a methodology for evaluating a sanitary landfill's technicalenvironmental viability, considering a Key Factors Matrix (KFM) for the possibility of its application in rural communities. The proposed methodology is based on: i) identification of preliminary and field data for assessment of the sector through the KFM, and ii) determination of the technical-environmental viability of an SL according to the aspects considered. The KFM allowed the Ayangue commune to be chosen for the location of the SL under certain precautions. Given this sector's tourist influence, solid waste accumulates 40 tons per day from the ninth year on. Therefore, it is recommended to bear in mind a possible restructuring of the SL, from a semi-mechanized system to a fully mechanized one.
\end{abstract}

\section{INTRODUCTION}

The management of non-hazardous solid waste and its final disposal constitutes a global health problem for cities and urban communities. Solid waste landfills are considered a source of environmental risks (especially in developing countries), especially in the contamination of water, air, and soil quality for agricultural production, transcending their impact beyond the area of sanitary protection. Therefore, it is vital to improving waste disposal systems with engineering works in harmony with the environment to mitigate environmental impacts $[1,2]$.

The solid waste landfill is the primary method for waste disposal, taking into account the economic advantages it represents and its adaptation to almost all types of waste [1], $[3,4]$. On the other hand, leachate treatment is considered one of the main problems, being a critical factor for public health and groundwater contamination and surface water [5].

Sanitary Landfills (SL) are useful for ecological and environmental conservation after the disposal of solid waste. However, in those with low technical-environmental management, they are the primary source of putrefactive odors, surface and underground contamination due to the leachate produced, causing diseases and other environmental damage. $[6,7]$. Therefore, the implementation of an SL is of great benefit under specific observations and technicalenvironmental details, which the authorities exercise for the correct orientation of the work personnel and proper handling of the leachates $[8,9]$.

Until recently, technical-environmental regulations were not used for the dumping of municipal solid waste, causing landfills to be fetid places with environmental and social problems [10]. As Noguera y Olivero (2010) [11] point out, the poor management of solid waste and leachate treatment are the leading causes of foul odors due to SL's poor management in Latin America. Therefore, it is necessary for environmental organizations' intervention to correct the sector's correct management and sustainability.

The increase in the population has a significant impact on the increase in the production of solid waste. Therefore, specific regulations regarding this waste have been established by the environmental agencies of countries worldwide [12]. Another essential aspect to mention is the land where the sanitary landfill will be implanted, which must not have active geological structures. Röben [13] says that "The ideal thing for building a landfill is if the land already has a geological 
barrier."

Sanitary landfills are civil works that, by their nature, produce various impacts on the environment, such as the use of land or the generation of polluting liquids and gases [14, 15], which can be mitigated by treating the soil technically, thus avoiding water pollution underground in the area. In this way, landfills do not cause nuisance and danger to public health or environmental safety [16].

The generation of liquids by the decomposition of organic matter can be managed using perforated pipes, which allow the capture and transport by the gravity of leachates to the evaporation lagoon, as stated by Álvarez and Suárez [17] at the "El Guayabal" landfill, located in Cúcuta-Colombia. On the other hand, the biogas produced by the SL, even hundreds of years after its closure, can be treated and used in the generation of thermal or electrical energy [18]. Thus control each negative impact produced by the SL and takes advantage of it properly, without damaging the environment and human health.

The main processes that occur in sanitary landfills (hydrological, degradation, settlement) are closely related to each other, in such a way that each design variable affects the others. Therefore, all these interactions must be taken into account to optimize the overall design of the SL. For example, if the intention is to exploit the SL volume as much as possible, the debris layer's height can be increased to reduce the space occupied by the intermediate covers. However, the consequences of this change in power generation or the amount of pollution emitted should be investigated. The conditions such as the climate or the type of waste generated in a specific community affect these interactions, preventing the criteria from being applicable in any geographic location [19].

The use of an SL has at least four initial advantages: a) reduce the environmental impact due to the use of unproductive lands; b) a relatively low investment (in case of manual and semi-mechanized landfill), compared to mechanized landfills; c) possibility of generating jobs, unskilled and cheap labour; and d) the production of methane gas to medium term, due to the decomposition of organic waste.

Therefore, landfills can be divided into three types according to the amount of waste generated and its population [20]. These can be:

- Mechanized sanitary landfill: For populations greater than 100,000 inhabitants that generate solid waste more significant than 40 tons per day.

- Semi-mechanized sanitary landfill: For populations between 40,000 and 100,000 inhabitants that generate waste between 20 and 40 tons per day.

- Manual sanitary landfill: For populations of less than 40,000 inhabitants that generate a maximum of 20 tons per day, where heavy machinery cannot be purchased due to lack of budget, logistics, and other aspects.

This work presents an evaluation methodology for the technical-environmental viability of a type of sanitary landfill that receives non-hazardous solid waste, which would be specifically focused on the rural parish of Manglaralto located in the north of the province of Santa Elena.

The reception of solid waste must consider the minimum risk against the hydrogeology of the place, the physical, chemical, and biological characteristics of the solid waste, the disposal methods, the risks and effects for the environment and public health, and especially the safety of operating personnel [21].

Therefore, is it possible that applying a Key Factors Matrix (KFM) allows making decisions for a Sanitary Landfill's technical-environmental viability, appropriate to the study area's geographic reality and the physical environment?

KFM considers aspects related to the physical environment of a given sector, which are considered to formulate the following hypothesis: The application of the matrix designed in this study will allow obtaining solid arguments in decisionmaking to determine if the chosen place is favorable or not in the technical-environmental viability of an SL.

The aims are to evaluate the main aspects of a study sector and the technical-environmental viability of an SL by implementing a Key Factors Matrix (KFM) to publicize the possibility of its application in other rural communities. In this way, achieve a definitive and comprehensive SL configuration without damaging the environment during its operation and without affecting the surrounding communities.

\section{Materials and methods}

\subsection{Site description}

The province of Santa Elena is located on the Ecuadorian coast and is divided into three central cantons: Santa Elena, La Libertad, and Salinas. It has a surface area of $3,762.8 \mathrm{~km}^{2}$ and has a population of 401,178 inhabitants (according to the population projection made by the INEC [22]), not to mention its sizeable national influx and foreign tourists.

This study focuses on the south-central coast of the country, north of the province of Santa Elena, where the solid waste generated comes from the Manglaralto Parish, whose final disposal has been established in the Río Chico sector, and is subsequently being planning its final disposal in the Ayangue sector (Figure 1). Manglaralto has a population of 37,163 inhabitants (projected until the end of 2020). It presents a semi-arid climate (average annual rainfall of $170 \mathrm{~mm}$ [23]) influenced by two marine currents: El Niño, which marks the equatorial winter warm and humid, and the cold of Humboldt, that presents variations between humid tropical climates and dry. Average annual temperatures vary from $23^{\circ} \mathrm{C}$ to $25^{\circ} \mathrm{C}$. There are seasonal rivers; that is, the surface flow depends on the winter season, while the water table increases with infiltration and descends in the dry season [23, 24].

The Manglaralto parish has excellent geological diversity that promotes tourist activity in the sector and its conservation of geosites and sustainable development in various areas, such as social, economic, environmental, and cultural [25, 26]. Its resilience is reflected in the management of drinking water through the coastal aquifer and the supply to its six communes, the conservation of geosites and increase of its tourist resource, the management of its wastewater through green filters, among other projects focused mainly on the progress and advancement of the community [27-29].

Due to the recent pandemic (COVID-19), the amount of solid waste has decreased during 2020. For practical purposes, the calculations focused on a typical situation in which tourism activity is present consecutively. 


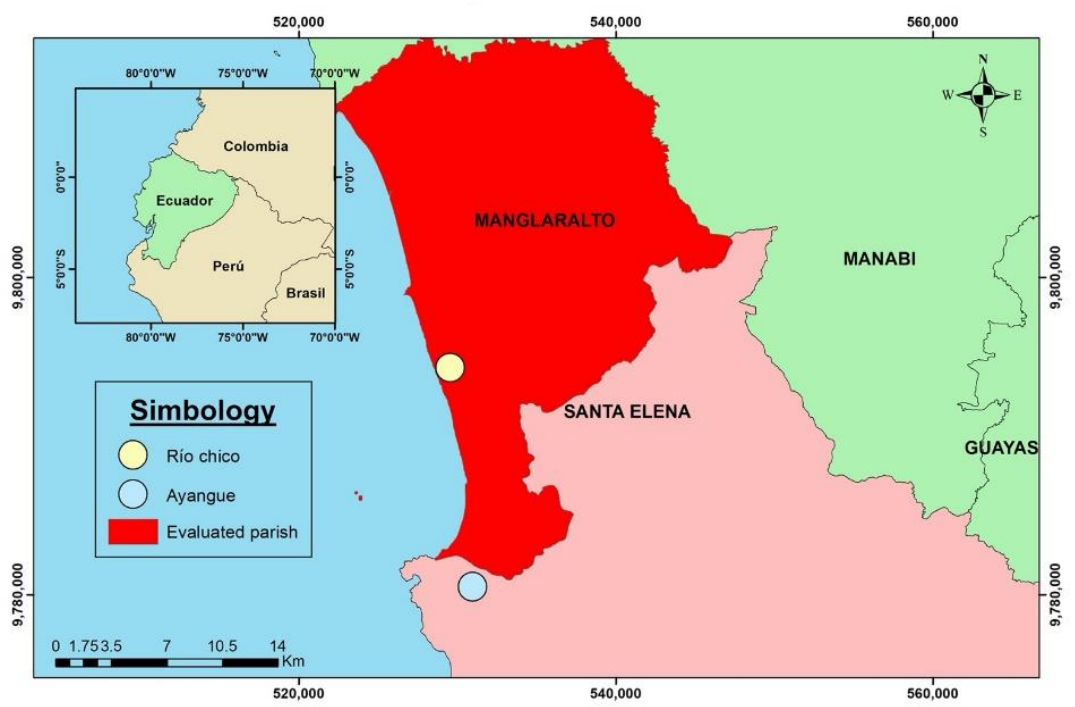

Figure 1. Map of Manglaralto Parish, Ecuador in South America

\subsection{Methodology}

The design of an SL requires applying a methodology that allows the collection of data, and therefore, covers the parameters framed in civil, sanitary, and environmental engineering.

Figure 2 shows the methodology proposed in this work. Phase I considers preliminary data such as population and review of studies carried out in the sector and data in the field, such as the amount of solid waste, generation of leachate, river conditions, geographical, topographic, and geological information the site. Based on these data, the implementation of the proposed KFM is carried out, and in this way, establish if it is feasible to implement the SL in a specific place. If feasible, in Phase II, the SL's aspects are analyzed considering the emplacement's area, the socio-economic and demographic analysis of the sector for the volumetric calculation of solid waste, and the area estimated during the next 15 years. Consideration of these aspects will make it possible to determine the technical-environmental viability of the SL.

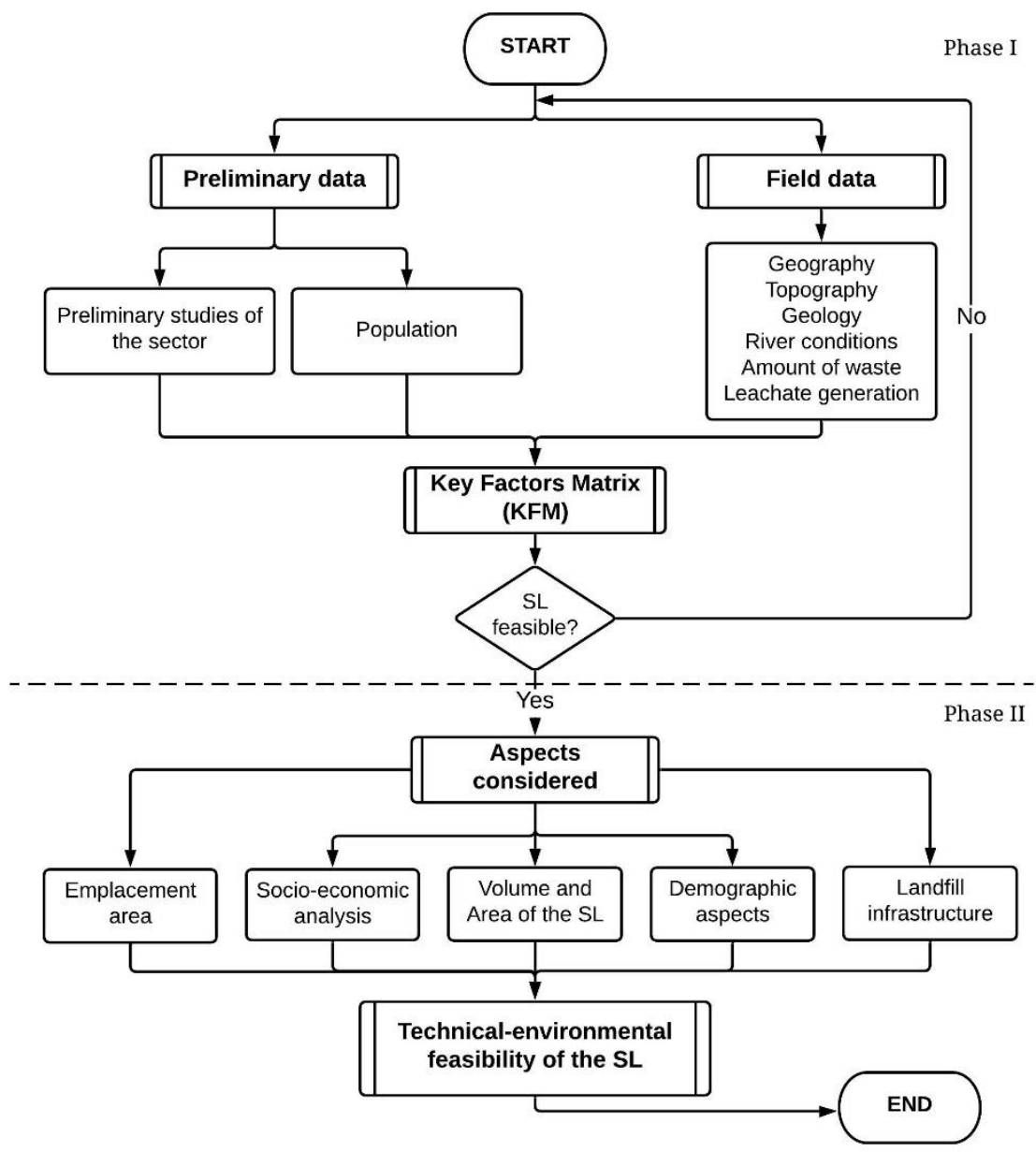

Figure 2. Methodology for the design of an SL 


\subsection{Development of a Key Factors Matrix (KFM) for Landfills}

The KFM is a complementary tool to an environmental impact matrix, a fundamental requirement before executing any work in urban or rural areas, thus providing solid arguments that promote an SL's technical-environmental viability. Therefore, a matrix is created applicable in all rural sectors and for all SL types (Table 1), prioritizing human health and harmony with the environment.

To the left of the aforementioned table (first column "N"), the rating corresponding to each row is observed. It is must be read keeping in mind the key factor of each column and its variants to be analyzed, thus providing a value in each factor that would later be analyzed using an equation (Eq. (1)).

The KFM is a pragmatic reference based on professional and research work for more than fifteen years in the study area. So, a matrix is configured to help a preliminary decision.
Therefore, the factors related to water (surface and underground), precipitation, permeability have a greater weight in the KFM equation.

Some factors impact more than others, so that, in addition to the valuations given, an appropriate weight is applied to each established parameter (Eq. (1)).

$$
\begin{gathered}
T V=2 T p+3 G w+3 S W+W+2 S R+T+2 P \\
+P o+2 k+2 S T+D C
\end{gathered}
$$

where: TV (Total Value), Tp (Topography), Gw (Groundwater), SW (Surface Water), W (Wind direction), SR (Solar Radiation), T (Temperature), P (Precipitation), Po (Population), k (Permeability), ST (Soil Type) and DC (Distance to Commune).

Figure 3 schematically represents each of these key factors analyzed, based mainly on professional experience in this study area.

\begin{tabular}{|c|c|c|c|c|c|c|}
\hline \multicolumn{2}{|c|}{ Assigned value (N) } & \multirow{2}{*}{$\begin{array}{c}\text { Topography } \\
\text { Flat }\end{array}$} & \multirow{2}{*}{$\begin{array}{l}\text { Groundwater } \\
\text { Nonexistence }\end{array}$} & \multirow{2}{*}{$\begin{array}{c}\text { Surface Water } \\
\mathrm{SW}>2 \mathrm{Km}\end{array}$} & \multirow{2}{*}{$\begin{array}{l}\text { Wind direction } \\
\text { Away from the } \\
\text { town }\end{array}$} & \multirow{2}{*}{$\begin{array}{c}\text { Solar Radiation } \\
\text { Direct and intense exposure }\end{array}$} \\
\hline & 3 & & & & & \\
\hline & 2 & Irregular & Great depth & $500 \mathrm{~m}<\mathrm{SW}<2 \mathrm{Km}$ & Near to town & $\begin{array}{c}\text { Direct and low intensity } \\
\text { exposure }\end{array}$ \\
\hline & 1 & Very irregular & Low depth & $\mathrm{SW}<500 \mathrm{~m}$ & $\begin{array}{l}\text { Towards from } \\
\text { town }\end{array}$ & Intercepted exposure \\
\hline $\mathbf{N}$ & Temperature & $\begin{array}{l}\text { Precipitation } \\
{[\mathrm{mm}]}\end{array}$ & Population & $\begin{array}{c}\text { Permeability } \\
{[\mathrm{cm} / \mathrm{s}]}\end{array}$ & Soil Type & Distance to Commune \\
\hline 3 & $\mathrm{~T}>25^{\circ} \mathrm{C}$ & $\mathrm{P}<500$ & Po $<40,000$ & $10^{-15}<\mathrm{k}<10^{-12}$ & Slime/Clay & $\mathrm{DC}>10 \mathrm{Km}$ \\
\hline 2 & $\begin{array}{c}20^{\circ} \mathrm{C}<\mathrm{T}< \\
25^{\circ} \mathrm{C}\end{array}$ & $500<\mathrm{P}<1,000$ & $\begin{array}{c}4 \times 10^{4}<\text { Po } \\
<10^{5}\end{array}$ & $10^{-11}<\mathrm{k}<10^{-7}$ & Sand & $500 \mathrm{~m}<\mathrm{DC}<2 \mathrm{Km}$ \\
\hline 1 & $\mathrm{~T}<20^{\circ} \mathrm{C}$ & $\mathrm{P}>1,000$ & Po $>10^{5}$ & $10^{-6}<\mathrm{k}<10^{-3}$ & Gravel & $\mathrm{DC}<500 \mathrm{~m}$ \\
\hline
\end{tabular}

Table 1. Key Factors Matrix (KFM)

Note: The assigned value are: $\mathrm{N}=3$ (Favourable), $\mathrm{N}=2$ (Intermediate), $\mathrm{N}=1$ (Unfavourable).

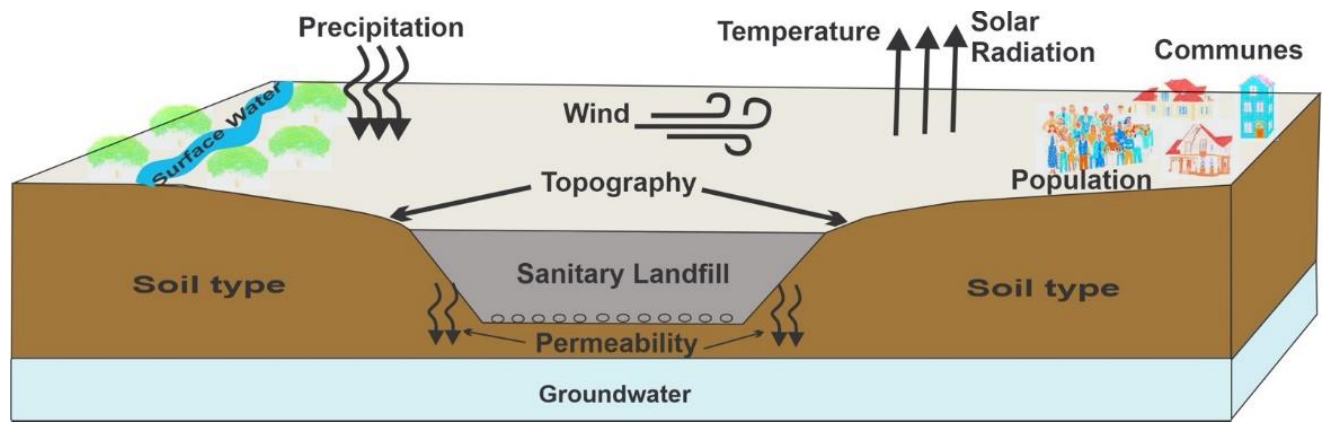

Figure 3. Schematic model and location of the key factors for KFM

\section{RESULTS}

\subsection{Key Factors Matrix for Landfill. (KFM)}

The KFM makes it possible to evaluate the Río Chico and Ayangue sector by analyzing each site's main aspects (Table 2 ). The total value (TV) allows determining the viability of the SL based on its qualitative and quantitative component, as shown below: $\mathrm{TV}>50$ : Constructible with minor precautions; $35<\mathrm{TV}<50$ : Constructible under essential considerations; $\mathrm{TV}<35$ : Not buildable.

Therefore, based on the data obtained in Table 2, the SL project's implementation is feasible in the Ayangue sector (TV $=58 / 60$ ). It is an option to solve the problem of the final disposal of solid waste.
Table 2. Evaluation through the KFM

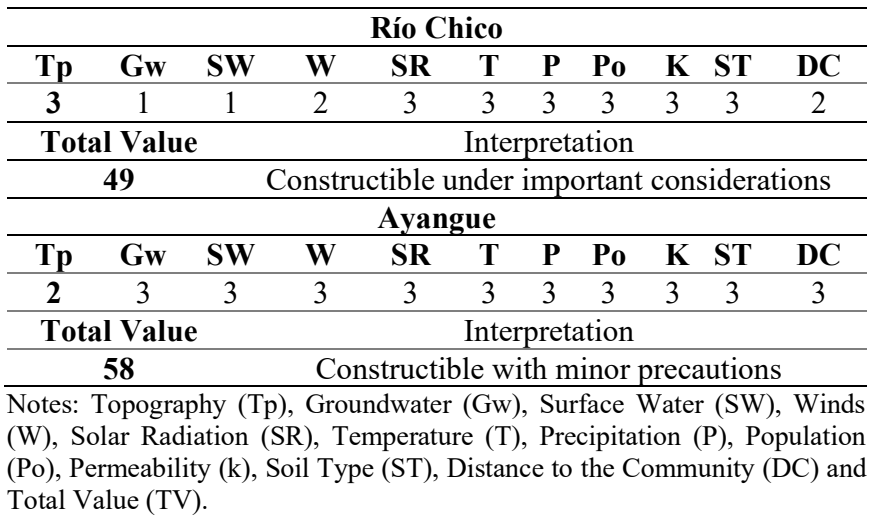




\subsection{Conditions of the study area}

The old landfills (in the open air) do not consider technicalenvironmental details, harming human health through the emission of gases carried by the wind and leachates that circulate through the ground, thus polluting green areas and water sources $[30,31]$. Therefore, for the Ayangue sector, it is necessary to establish adequate coordination between the municipalities and the health authorities, thus achieving the evaluation of areas with soft reliefs and low slopes.

Ayangue has access roads suitable for the transfer of collection vehicles, workers, and machinery destined for the SL. Its knowledge and operation must be agreed with the community to accept and collaborate with the inhabitants.

\subsection{Socio-economic analysis}

The economy of the province of Santa Elena (specifically in Manglaralto) is based mainly on maritime and tourist resources, so it receives a large influx of people during the holiday and festive season. The collection of solid waste in the Manglaralto parish is carried out six days a week, which allows a calculation more in line with the sector's reality.

\subsection{Demographic aspects}

The population increase of the parish and tourism in the sector influences the production of solid waste. Therefore, all the demographic aspects present for the SL's technicalenvironmental viability must be considered (Table 3 ).

Table 3. Demographic aspects considerate

\begin{tabular}{|c|c|}
\hline $\begin{array}{c}\text { Current } \\
\text { population }\end{array}$ & $\begin{array}{c}\text { The number of autochthonous inhabitants of the Manglaralto parish allows starting the calculations regarding population } \\
\text { growth and solid waste produced in a given time. }\end{array}$ \\
\hline $\begin{array}{c}\text { Future } \\
\text { population }\end{array}$ & $\begin{array}{l}\text { It is essential to estimate the future population that the community will have in the next } 15 \text { years to calculate the SL's } \\
\text { volume and area throughout its useful life. }\end{array}$ \\
\hline $\begin{array}{c}\text { Floating } \\
\text { population }\end{array}$ & $\begin{array}{l}\text { It corresponds to an adjustment of the population increase due to the tourist influence of the sector. Therefore, according to } \\
\text { Espinel Ortiz et al., } 2014 \text { [32], the relationship between the } 116 \text { days off in Ecuador and } 365 \text { days a year must be } \\
\text { considered, which corresponds to an adjustment of } 32 \% \text { of the annual population. }\end{array}$ \\
\hline
\end{tabular}

The population growth rate is calculated for the Manglaralto parish (Table 4), according to the 2001 and 2010 census population in Ecuador, carried out by the National Institute of Statistics and Censuses (INEC, acronym in Spanish), which is in charge of collecting economic and environmental data and sociodemographic of the country [33].

Table 4. Population growth rate

\begin{tabular}{cccc}
\hline $\begin{array}{c}\text { Census } \\
\mathbf{2 0 0 1}\end{array}$ & $\begin{array}{c}\text { Census } \\
\mathbf{2 0 1 0}\end{array}$ & $\begin{array}{c}\text { Growth rate } \\
(\mathbf{\%})\end{array}$ & $\begin{array}{c}\text { Current population } \\
(\mathbf{2 0 2 0})\end{array}$ \\
\hline $\mathbf{2 3 , 4 3 6}$ & 29,512 & 2.3 & 37,163 \\
\hline
\end{tabular}

Table 5 shows the total population increase during the useful life of the SL, which is equal to the sum of the future population (Eq. (2)) and the annual adjustment of this due to the floating population (Table 3 ).

$$
F_{p}=C_{p}(1+r)^{t}
$$

The acronym of each equation is shown in Table 6 .

Table 5. Population growth (15 years)

\begin{tabular}{cccc}
\hline Year & $\begin{array}{c}\text { Future } \\
\text { population }\end{array}$ & $\begin{array}{c}\text { Floating } \\
\text { population }\end{array}$ & $\begin{array}{c}\text { Total population } \\
\text { per year }\end{array}$ \\
\hline $\mathbf{2 0 2 1}$ & 38,030 & 12,170 & 50,199 \\
$\mathbf{2 0 2 2}$ & 38,917 & 12,453 & 51,370 \\
$\mathbf{2 0 2 3}$ & 39,824 & 12,744 & 52,568 \\
$\mathbf{2 0 2 4}$ & 40,753 & 13,041 & 53,794 \\
$\mathbf{2 0 2 5}$ & 41,703 & 13,345 & 55,048 \\
$\mathbf{2 0 2 6}$ & 42,676 & 13,656 & 56,332 \\
$\mathbf{2 0 2 7}$ & 43,671 & 13,975 & 57,646 \\
$\mathbf{2 0 2 8}$ & 44,690 & 14,301 & 58,990 \\
$\mathbf{2 0 2 9}$ & 45,732 & 14,634 & 60,366 \\
$\mathbf{2 0 3 0}$ & 46,798 & 14,975 & 61,774 \\
$\mathbf{2 0 3 1}$ & 47,890 & 15,325 & 63,214 \\
$\mathbf{2 0 3 2}$ & 49,006 & 15,682 & 64,688 \\
$\mathbf{2 0 3 3}$ & 50,149 & 16,048 & 66,197 \\
$\mathbf{2 0 3 4}$ & 51,319 & 16,422 & 67,741 \\
$\mathbf{2 0 3 5}$ & 52,515 & 16,805 & 69,320 \\
\hline
\end{tabular}

\subsection{Calculation of the volume and area needed for Sanitary Landfill}

\subsubsection{Per capita production}

According to the following equation (Eq. (3)), the per capita production (pcp) is the amount of solid waste per inhabitant, so:

$$
p c p=\frac{S W c \text { in } a d a y}{T p o}
$$

For calculating the pcp of each year (Table 7), the mathematical method (Rule of three) is used between the Pop and its pcp of this and next year.

\subsubsection{Total solid waste production}

The production of Solid Waste daily $\left(\mathrm{SW}_{\mathrm{d}}\right)$ will be calculated using the following equation (Eq. (4)).

$$
S W_{d}=T p o * p c p
$$

Table 6 shows the daily, annual, and accumulated amount of the 15 years of the SL's useful life.

\subsubsection{Solid waste volume}

The daily volume (Eq. (5)) of solid waste calculated, considering that the accumulation of waste is given seven days a week, but the collection is six days.

$$
V_{\text {daily }}=\left(S W_{d} / D_{c s w}\right) * \frac{7(\text { day of accumulation })}{6(\text { day of collection })}
$$

For known, the annual volume of compacted solid waste (Eq. (6)), the following equation is used:

$$
V_{c s w}=V_{\text {daily }} * 365
$$

The equation for the annual volume of stabilized solid waste (Eq. (7)) is: 


$$
V_{s s w}=S W_{d} / D_{s s w} * 365
$$

The required volume of cover material, total volume, and total area.

The Cover material $(\mathrm{Cm})$ (defined as the minimum amount of land needed to cover solid waste that has just been compacted. See Eq. (8)), is estimated that fluctuates between $20 \%$ and $25 \%$ of the volume of compacted solid waste, but in this case, it will take the value of $20 \%$.

$$
C m=V_{c s w} * 20 \%
$$

Total volume and total area required

The result of the total volume of the SL $\left(\mathrm{V}_{\mathrm{SL}}\right)$ (see Eq. (9)) in the 15 years shown in the following Table 8 , and its calculation is given with the following equation:

$$
V_{S L}=V_{s s w}+C m
$$

For known the total area required for the SL $\left(\mathrm{A}_{\mathrm{SL}}\right)$ (Table 9), the height ( 3 meters for a year) concerning the required annual volume must be considered, managing to determine the following expression (Eq. (10)):

$$
A_{S L}=V_{S L} / 3
$$

Table 6. Equations' acronym

\begin{tabular}{cc}
\hline Acronym & Meaning \\
\hline $\mathbf{F p}$ & Future population \\
$\mathbf{C p}$ & Current population \\
$\mathbf{r}$ & Population growth rate $(2.3 \%)$ \\
$\mathbf{t}$ & Years interval \\
$\mathbf{p c p}$ & per capita production \\
$\mathbf{T p o}$ & Total population \\
$\mathbf{S W}_{\mathbf{c}}$ & Solid Waste collected \\
$\mathbf{S W}$ d & Solid Waste daily \\
$\mathbf{V}_{\text {daily }}$ & Volume of solid waste available in one day \\
$\mathbf{D}_{\text {csw }}$ & Density of compacted solid wastes $\left(300 \mathrm{~kg} / \mathrm{m}^{3}\right)$ \\
$\mathbf{D}_{\text {ssw }}$ & Density of stabilized solid wastes $\left(500 \mathrm{~kg} / \mathrm{m}^{3}\right)$ \\
$\mathbf{V}_{\text {csw }}$ & Volume of compacted solid waste \\
$\mathbf{V}_{\text {ssw }}$ & Volume of stabilized solid waste \\
$\mathbf{C m}$ & Cover material \\
$\mathbf{V}_{\text {SL }}$ & Total volume of the SL \\
$\mathbf{A s L}$ & Total area required for the SL \\
\hline
\end{tabular}

Table 7. Per capita production and accumulation of solid waste

\begin{tabular}{lccccc}
\hline & & & \multicolumn{3}{c}{ Solid waste quantity } \\
\cline { 4 - 6 } Years & $\begin{array}{c}\text { Total } \\
\text { population }\end{array}$ & $\begin{array}{c}\text { ppc } \\
\text { kg/hab/día }\end{array}$ & Daily & Annual & $\begin{array}{c}\text { Accumulated } \\
\text { (Accum.) }\end{array}$ \\
\cline { 4 - 6 } & & & tons/day & tons/year & tons \\
\hline $\mathbf{2 0 2 1}$ & $50,199.48$ & 0.57 & 28.61 & $10,444.00$ & $10,444.00$ \\
$\mathbf{2 0 2 2}$ & $51,370.14$ & 0.58 & 29.96 & $10,936.79$ & $21,380.80$ \\
$\mathbf{2 0 2 3}$ & $52,568.10$ & 0.60 & 31.38 & $11,452.84$ & $32,833.63$ \\
$\mathbf{2 0 2 4}$ & $53,793.99$ & 0.61 & 32.86 & $11,993.23$ & $44,826.86$ \\
$\mathbf{2 0 2 5}$ & $55,048.48$ & 0.63 & 34.41 & $12,559.12$ & $57,385.97$ \\
$\mathbf{2 0 2 6}$ & $56,332.21$ & 0.64 & 36.03 & $13,151.71$ & $70,537.68$ \\
$\mathbf{2 0 2 7}$ & $57,645.89$ & 0.65 & 37.73 & $13,772.26$ & $84,309.94$ \\
$\mathbf{2 0 2 8}$ & $58,990.20$ & 0.67 & 39.51 & $14,422.09$ & $98,732.03$ \\
$\mathbf{2 0 2 9}$ & $60,365.86$ & 0.69 & 41.38 & $15,102.58$ & $113,834.61$ \\
$\mathbf{2 0 3 0}$ & $61,773.60$ & 0.70 & 43.33 & $15,815.18$ & $129,649.79$ \\
$\mathbf{2 0 3 1}$ & $63,214.16$ & 0.72 & 45.37 & $16,561.41$ & $146,211.20$ \\
$\mathbf{2 0 3 2}$ & $64,688.33$ & 0.73 & 47.51 & $17,342.84$ & $163,554.05$ \\
$\mathbf{2 0 3 3}$ & $66,196.87$ & 0.75 & 49.76 & $18,161.15$ & $181,715.19$ \\
$\mathbf{2 0 3 4}$ & $67,740.58$ & 0.77 & 52.10 & $19,018.07$ & $200,733.26$ \\
$\mathbf{2 0 3 5}$ & $69,320.30$ & 0.79 & 54.56 & $19,915.42$ & $220,648.68$ \\
\hline
\end{tabular}

Table 8. Total sanitary landfill volume $\left(\mathrm{m}^{3}\right)$

\begin{tabular}{cccccccc}
\hline \multirow{2}{*}{ Year } & \multicolumn{2}{c}{ Compacted solid waste } & \multicolumn{2}{c}{ Cover material } & Stabilized solid waste & \multicolumn{2}{c}{ Sanitary Landfill } \\
\cline { 2 - 8 } & Daily & Annual & Daily & Annual & $\left(\mathbf{m}^{3} /\right.$ year $)$ & VSL & Vaccum. $^{\text {ach }}$ \\
\hline $\mathbf{2 0 2 1}$ & 111.28 & $40,615.56$ & 22.26 & $8,123.11$ & $7,624.12$ & $48,239.69$ & $48,239.69$ \\
$\mathbf{2 0 2 2}$ & 116.53 & $42,531.97$ & 23.31 & $8,506.39$ & $7,983.86$ & $50,515.83$ & $98,755.52$ \\
$\mathbf{2 0 2 3}$ & 122.02 & $44,538.80$ & 24.40 & $8,907.76$ & $8,360.57$ & $52,899.37$ & $151,654.89$ \\
$\mathbf{2 0 2 4}$ & 127.78 & $46,640.33$ & 25.56 & $9,328.07$ & $8,755.06$ & $55,395.38$ & $207,050.28$ \\
$\mathbf{2 0 2 5}$ & 133.81 & $48,841.01$ & 26.76 & $9,768.20$ & $9,168.15$ & $58,009.16$ & $265,059.44$ \\
$\mathbf{2 0 2 6}$ & 140.12 & $51,145.53$ & 28.02 & $10,229.11$ & $9,600.75$ & $60,746.27$ & $325,805.71$ \\
$\mathbf{2 0 2 7}$ & 146.74 & $53,558.78$ & 29.35 & $10,711.76$ & $10,053.75$ & $63,612.53$ & $389,418.24$ \\
$\mathbf{2 0 2 8}$ & 153.66 & $56,085.90$ & 30.73 & $11,217.18$ & $10,528.13$ & $66,614.03$ & $456,032.27$ \\
$\mathbf{2 0 2 9}$ & 160.91 & $58,732.26$ & 32.18 & $11,746.45$ & $11,024.88$ & $69,757.15$ & $525,789.42$ \\
$\mathbf{2 0 3 0}$ & 168.50 & $61,503.49$ & 33.70 & $12,300.70$ & $11,545.08$ & $73,048.58$ & $598,837.99$ \\
$\mathbf{2 0 3 1}$ & 176.45 & $64,405.48$ & 35.29 & $12,881.10$ & $12,089.83$ & $76,495.31$ & $675,333.30$ \\
$\mathbf{2 0 3 2}$ & 184.78 & $67,444.39$ & 36.96 & $13,488.88$ & $12,660.28$ & $80,104.67$ & $755,437.96$ \\
$\mathbf{2 0 3 3}$ & 193.50 & $70,626.69$ & 38.70 & $14,125.34$ & $13,257.64$ & $83,884.33$ & $839,322.29$ \\
$\mathbf{2 0 3 4}$ & 202.63 & $73,959.15$ & 40.53 & $14,791.83$ & $13,883.19$ & $87,842.34$ & $927,164.63$ \\
$\mathbf{2 0 3 5}$ & 212.19 & $77,448.84$ & 42.44 & $15,489.77$ & $14,538.25$ & $91,987.10$ & $1,019,151.72$ \\
\hline
\end{tabular}


Table 9. Total sanitary landfill area (hectares)

\begin{tabular}{cccc}
\hline & \multicolumn{2}{c}{ Volume } & \multicolumn{2}{c}{ Area } \\
\cline { 2 - 4 } Year & \multirow{2}{*}{ VSL } & AsL & A (accum.) \\
& & & \\
\hline $\mathbf{2 0 2 1}$ & $48,239.69$ & 1.61 & 1.61 \\
$\mathbf{2 0 2 2}$ & $50,515.83$ & 1.68 & 3.29 \\
$\mathbf{2 0 2 3}$ & $52,899.37$ & 1.76 & 5.06 \\
$\mathbf{2 0 2 4}$ & $55,395.38$ & 1.85 & 6.90 \\
$\mathbf{2 0 2 5}$ & $58,009.16$ & 1.93 & 8.84 \\
$\mathbf{2 0 2 6}$ & $60,746.27$ & 2.02 & 10.86 \\
$\mathbf{2 0 2 7}$ & $63,612.53$ & 2.12 & 12.98 \\
$\mathbf{2 0 2 8}$ & $66,614.03$ & 2.22 & 15.20 \\
$\mathbf{2 0 2 9}$ & $69,757.15$ & 2.33 & 17.53 \\
$\mathbf{2 0 3 0}$ & $73,048.58$ & 2.43 & 19.96 \\
$\mathbf{2 0 3 1}$ & $76,495.31$ & 2.55 & 22.51 \\
$\mathbf{2 0 3 2}$ & $80,104.67$ & 2.67 & 25.18 \\
$\mathbf{2 0 3 3}$ & $83,884.33$ & 2.80 & 27.98 \\
$\mathbf{2 0 3 4}$ & $87,842.34$ & 2.93 & 30.91 \\
$\mathbf{2 0 3 5}$ & $91,987.10$ & 3.07 & 33.97 \\
\hline
\end{tabular}

\section{DISCUSSION}

The configuration of the KFM consists of the analysis of the main factors that influence rural sectors (Table 1), such as Topography, Groundwater, Surface Water, Winds, Solar Radiation, Temperature, Precipitation, Population, Permeability, Type of Land, and Distance to the Community. It complies with the review carried out by Rezaeisabzevar, Bazargan, and Zohourian (2020) [34]. They focus on the main evaluation methods and the most used criteria for the site's analysis and selection, which would comply with the acceptance and feasibility technical-environmental for an SL's subsequent design.

Results suggest an annual area (in hectares) of 1.61 in the first year and 3.07 in year 15 of the useful life of the SL (Table 9), considering a height of 3 meters as proposed by the Ministry of the Environment and Water [20]. They are projecting a total area of 33.97 hectares in the technicalenvironmental viability of the SL. Therefore, the Sanitary Landfill of type Manual cannot be considered for this project since the estimated area exceeds Jaramillo's proposal [35].

The population projection for this project (Table 5) starts from 50,199 inhabitants and ends with 69,320 (estimated in the 15 years of the useful life of the SL), producing solid waste daily, ranging between 28 tons/day of the first year and 54 tons/day of the last year. Table 7 shows the amount of solid waste produced during the first eight years (less than 40 tons/day), thus complying with the conditions of a Semimechanized Sanitary Landfill, as stated by the Ministry of the Environment and Water [20]. However, from the ninth year, solid waste production exceeds 40 tons/day (Table 7), which indicates that the ideal SL for this amount of garbage is the Mechanized Sanitary Landfill.

The Ayangue sector meets the acceptance criteria for the technical-environmental viability of an SL (Table 2). It has asphalt roads that provide adequate access to any area far from the populated area at any time of the year. Its only drawback is the topography of the place, which can be analyzed through various evaluative criteria and implementation of GIS (geographic information system), as stated by Md Mainul, Sk et al. [36].

\section{CONCLUSIONS}

The evaluation carried out in Ayangue, through the KFM, provides a total value of 58/60 (Table 2), thus demonstrating the technical-environmental viability of the SL under certain precautions, focusing on suitable areas for its location according to the topography of this sector. On the other hand, in Río Chico's commune, manifests this sector's unacceptable conditions (Table 2), such as the direct contamination of surface waters and the coastal aquifer due to leachate seepage, in addition to the emanation of gases that the wind transports that to the nearest towns. It allowed to recommend the new SL in Ayangue and justify the SL's technical closure in the Río Chico sector.

According to the results obtained in table 7, the SL located in Ayangue would meet the technical-environmental viability of a Semi-mechanized Sanitary Landfill during the first eight years of its useful life, with a partial implementation of machinery in the transfer of material. As of the ninth year, the production of solid waste exceeds 40 tons/day, for which it is determined that the operating system of the SL must be modified to Mechanized Landfill. Therefore, heavy machinery must be implemented for the transfer, compaction, and filling of the SL.

For the SL's technical-environmental viability, a stable and impermeable soil (preferably clayey) should be considered, and with a slope of $3 \%$ to $12 \%$ of inclination, for the adequate evacuation of leachates [20]. Through this project, the population benefits by generating unskilled labour, available in abundance in developing countries and showing a clear and easy alternative to mitigate the different environmental impacts generated mainly by the open deposition of solid waste, thus improving the quality of life of the inhabitants and surrounding populations.

The SL that is projected in Ayangue aims to store the solid waste of the Manglaralto parish continuously. A maintenance plan and permanent technical monitoring of gas and leachate emissions must be carried out, for the future reuse of the land, especially in recreation and ecological areas. As was the largest landfill globally, "Fresh Kill Landfill" is a recognized ecological park [37].

\section{REFERENCES}

[1] Vaverková, M.D. (2019). Landfill impacts on the environment review. Geosci., 9(10): 1-16. https://doi.org/10.3390/geosciences9100431

[2] Makarenko, N., Budak, O. (2017). Waste management in Ukraine: Municipal solid waste landfills and their impact on rural areas. Annals of Agrarian Science, 15(1): 80-87. https://doi.org/10.1016/j.aasci.2017.02.009

[3] Jovanov, D., Vujić, B., Vujić, G. (2018). Optimization of the monitoring of landfill gas and leachate in closed methanogenic landfills. Journal of Environmental Management, 216: 32-40. https://doi.org/10.1016/j.jenvman.2017.08.039

[4] Feng, S.J., Chen, Z.W., Chen, H.X., Zheng, Q.T., Liu, R. (2018). Slope stability of landfills considering leachate recirculation using vertical wells. Engineering Geology, 241: 76-85. https://doi.org/10.1016/j.enggeo.2018.05.013

[5] Biglarijoo, N., Mirbagheri, S.A., Bagheri, M., Ehteshami, M. (2017). Assessment of effective parameters in landfill 
leachate treatment and optimization of the process using neural network, genetic algorithm and response surface methodology. Process Safety and Environmental Protection, 106: 89-103. https://doi.org/10.1016/j.psep.2016.12.006

[6] Mishra, S., Tiwary, D., Ohri, A., Agnihotri, A.K. (2019). Impact of Municipal Solid Waste Landfill leachate on groundwater quality in Varanasi, India. Groundwater for Sustainable Development, 9: 100230. https://doi.org/10.1016/j.gsd.2019.100230

[7] Gómez-Puentes, F.J., Reyes-López, J.A., López, D.L., Carreón-Diazconti, C., Belmonte-Jiménez, S. (2014). Geochemical processes controlling the groundwater transport of contaminants released by a dump in an arid region of México. Environmental Earth Sciences, 71(2): 609-621. https://doi.org/10.1007/s12665-013-2456-2

[8] Diaz, L.F., Savage, G.M., Eggerth, L.L. (2005). Alternatives for the treatment and disposal of healthcare wastes in developing countries. Waste Management, 25(6):

626-637 https://doi.org/10.1016/j.wasman.2005.01.005

[9] Renou, S., Givaudan, J.G., Poulain, S., Dirassouyan, F., Moulin, P. (2008). Landfill leachate treatment: Review and opportunity. Journal of Hazardous Materials, 150(3): 468-493. https://doi.org/10.1016/j.jhazmat.2007.09.077

[10] Soltani, A., Sadiq, R., Hewage, K. (2016). Selecting sustainable waste-to-energy technologies for municipal solid waste treatment: A game theory approach for group decision-making. Journal of Cleaner Production, 113: 388-399. https://doi.org/10.1016/j.jclepro.2015.12.041

[11] Noguera, K.M., Olivero, J.T. (2010). Los Rellenos Sanitarios En Latinoamérica: Caso Colombiano Landfills In Latin America: Colombian Case Por.

[12] Talaiekhozani, A., Nematzadeh, S., Eskandari, Z., Dehkordi, A.A., Rezania, S. (2018). Gaseous emissions of landfill and modeling of their dispersion in the atmosphere of Shahrekord, Iran. Urban Climate, 24: 852 862. https://doi.org/10.1016/j.uclim.2017.10.005

[13] Röben, E. (2002). Diseño, construcción, operación y cierre de rellenos sanitarios municipales. Municipalidad de Loja. Ecuador.

[14] Slack, R.J., Gronow, J.R., Voulvoulis, N. (2005). Household hazardous waste in municipal landfills: contaminants in leachate. Science of the Total Environment, $337(1-3)$ : 119-137. https://doi.org/10.1016/j.scitotenv.2004.07.002

[15] León-Gómez, H.D., Cruz-Vega, C.R., Dávila-Pórcel, R.A., Velasco-Tapia, F., Chapa-Guerrero, J.R. (2015). Impacto del lixiviado generado en el relleno sanitario municipal de Linares (Nuevo León) sobre la calidad del agua superficial Y subterránea. Revista Mexicana de Ciencias Geológicas, 32(3): 514-526.

[16] Haruna, R.L., Alaga, T.A., Gajere, E.N., Chioma, U., Amos, S.I. (2016). Landfill site selection for solid waste management in Karu Lga, Nasarawa state, Nigeria. International Journal of Trend in Research \& Development, 3(6): 436-467.

[17] Álvarez Contreras, A., Suárez Gelvez, J.H. (2011). Tratamiento biológico del lixiviado generado en el relleno sanitario "El Guayabal" de la ciudad San José de Cúcuta. Revista Científica Ingeniería y Desarrollo, 20(20): 95-105.

[18] Camargo, Y., Vélez, A. (2009). Emisiones de biogás producidas en rellenos sanitarios. In II Simposio
Iberoamericano de Ingeniería de Residuos. Colombia.

[19] Cuartas, M., López, A., Pérez, F., Lobo, A. (2018). Analysis of landfill design variables based on scientific computing. Waste Management, 71: 287-300. https://doi.org/10.1016/j.wasman.2017.10.043

[20] Ministerio del Medio Ambiente y Agua, Guía para el Diseño, Construcción, Operación, Mantenimiento y Cierre de Rellenos Sanitarios, 1st ed. Bolivia, 2012. https://docplayer.es/26754277-Guiapara-el-disenoconstruccion-operacion-mantenimientoy-cierre-derellenos-sanitarios.html.

[21] Eguizabal, B., Marizol, R. (2009). Guía de diseño, construcción, operación, mantenimiento y cierre de relleno sanitario manual.

[22] INEC (2020). Proyecciones Poblacionales. https://www.ecuadorencifras.gob.ec/proyeccionespoblacionales/, accessed on Feb. 17, 2021.

[23] Carrión-Mero, P., Montalván, F.J., Morante-Carballo, F., Loor-Flores de Valgas, C., Apolo-Masache, B., Heredia, J. (2021). Flow and transport numerical model of a coastal aquifer based on the hydraulic importance of a dyke and its impact on water quality: ManglaraltoEcuador. Water, 13(4): 443. https://doi.org/10.3390/w13040443

[24] GAD (2021). Manglaralto parish. http://www.gadmanglaralto.gob.ec/.

[25] Gricelda, H.F., Paúl, C.M., Niurka, A.M. (2018). Participatory Process for Local Development: Sustainability of Water Resources in Rural Communities: Case Manglaralto-Santa Elena, Ecuador. In Handbook of Sustainability Science and Research. Springer, Cham, pp. 663-676. https://doi.org/10.1007/978-3-319-63007-6_41

[26] Herrera, G., Carrión, P., Briones, J. (2018). Geotourism potential in the context of the Geopark project for the development of Santa Elena province, Ecuador. WIT Transactions on Ecology and the Environment, 217: 557568. https://doi.org/10.2495/SDP180481

[27] Carballo, F.M., Brito, L.M., Mero, P.C., Aguilar, M. A., Ramírez, J.T. (2019). Urban wastewater treatment through a system of green filters in the Montañita commune, Santa Elena, Ecuador. WIT Trans. Ecol. Environ, 239: 233-249. https://doi.org/10.2495/WS190211

[28] Herrera Franco, G., Carrión Mero, P., Briones Bitar, J. (2019). Management practices for a sustainable community and its impact on development, ManglaraltoSanta elena, Ecuador. In Proceedings of the 17thLACCEI International Multi-Conference for Engineering, Education, and Technology, Montego Bay, Jamaica, 24-26. https://doi.org/10.18687/LACCEI2019.1.1.130

[29] Herrera-Franco, G., Carrión-Mero, P., Aguilar-Aguilar, M., Morante-Carballo, F., Jaya-Montalvo, M., MorilloBalsera, M.C. (2020). Groundwater resilience assessment in a communal coastal aquifer system. The Case of Manglaralto in Santa Elena, Ecuador. Sustainability, 12(19): 8290. https://doi.org/10.3390/su12198290

[30] Mataloni, F., Badaloni, C., Golini, M.N., Bolignano, A., Bucci, S., Sozzi, R., Ancona, C. (2016). Morbidity and mortality of people who live close to municipal waste landfills: A multisite cohort study. International Journal of $\quad$ Epidemiology, 45(3): 806-815. https://doi.org/10.1093/ije/dyw052 
[31] Porfírio, B., Gomes, J., Janissek, P.R. (2014). Avaliação de risco à saúde humana do aterro controlado de Morretes. Engenharia Sanitaria e Ambiental, 19(4): 441-452. https://doi.org/10.1590/S1413-41522014019000000444

[32] Espinel Ortiz, A.A., Castiblanco Solorzano, G.A., Guerrero Rojas, Á.D., Prada Yara, G.A. (2014). Estudio de prefactibilidad para el sistema de acueducto complementario de la cabecera municipal de la Vega, Cundinamarca. http://hdl.handle.net/10654/10837

[33] INEC. (2010). Registro del censo poblacional - Ecuador. 2010. https://www.ecuadorencifras.gob.ec/?s=población.

[34] Rezaeisabzevar, Y., Bazargan, A., Zohourian, B. (2020). Landfill site selection using multi criteria decision making: Focus on influential factors for comparing locations. Journal of Environmental Sciences.

[35] Jaramillo, J. (2002). Guía para el diseño, construcción y operación de rellenos sanitarios manuales. Centro Panamericano de Ingeniería Sanitaria y Ciencias del Ambiente, 19-24.

[36] Sk, M.M., Ali, S.A., Ahmad, A. (2020). Optimal sanitary landfill site selection for solid waste disposal in durgapur city using geographic information system and multicriteria evaluation technique. KN-Journal of Cartography and Geographic Information, 70(4): 163-180. https://doi.org/10.1007/s42489-020-00052-1

[37] Hoefer, W., Gallagher, F., Hyslop, T., Wibbelt, T.J., Ravit, B. (2016). Environmental reviews and case studies: unique landfill restoration designs increase opportunities to create urban open space. Environmental Practice, 18(2): 106-115. 